\title{
Analisis Manajemen Risiko Penularan Virus COVID-19 Pada Dokter dan Perawat Di Rumah Sakit X
}

\author{
Tiffani Dwiarine Afifa, Wiku Bakti Bawono Adisasmito \\ Universitas Indonesia \\ E-mail: tiffaniafifa@gmail.com
}

\begin{abstract}
Abstrak
Selama pandemi COVID-19, rumah sakit perlu melakukan upaya perlindungan terhadap dokter dan perawat, yaitu dengan penerapan manajemen risiko yang baik. Dalam penelitian ini dilakukan analisis penerapan manajemen risiko terhadap pencegahan penularan infeksi COVID-19 pada dokter dan perawat di RS X dengan cara menganalisis elemen penting dalam penerapannya serta melihat hubungan elemen tersebut terhadap penilaian penerapan manajemen risiko. Penelitian ini menggunakan metode penelitian kuantitatif dan kualitatif paralel konvergen yang diolah secara univariat dan bivariat. Data dikumpulkan melalui wawancara mendalam dan penyebaran kuesioner daring. Hasil: Rumah sakit telah melakukan upaya demi tercapainya lingkungan kerja yang aman, seperti pembuatan area khusus COVID, penyediaan APD yang cukup, serta pengaturan durasi shift. Didapatkan korelasi signifikan ( $p$-value $<0.05)$ elemen yang diteliti dengan penilaian penerapan manajemen risiko, dengan nilai uji Spearman tertinggi 0.607 pada elemen komunikasi dan information. Kesimpulan: Elemen-elemen yang diteliti memiliiki hubungan terhadap penilaian penerapan manajemen risiko di RS X. Telah dilakukan berbagai upaya untuk melindungi dokter dan perawat dengan penerapan manajemen risiko yang sudah berjalan cukup baik, terlihat dari menurunnya angka terinfeksi pada pemeriksaan rutin. Masih ditemukan hambatan berupa keterbatasan sumber daya, karakter yang kurang disiplin, serta belum terciptanya komunikasi dan lingkungan jujur dengan sepenuhnya.

Kata kunci: manajemen risiko, COVID-19, dokter, perawat
\end{abstract}

\section{Abstract}

During the COVID-19 pandemic, hospitals need to make efforts to protect doctors and nurses, namely by implementing good risk management. In this study, an analysis of the application of risk management was carried out to prevent the transmission of COVID-19 infection to doctors and nurses at RS X by analyzing the important elements in its application and seeing the relationship of these elements to the assessment of the application of risk management. This study uses a convergent parallel quantitative and qualitative research method that is processed by univariate and bivariate. Data were collected through in-depth interviews and the distribution of online questionnaires. Result: The hospital has made efforts to achieve a safe work environment, such as the creation of a special COVID area, providing sufficient PPE, and adjusting shift duration. There was a significant correlation ( $p$-value $<0.05$ ) of the elements studied with the assessment of the application of risk management, with the highest Spearman test value of 0.607 on the elements of communication and information. Conclusion: The elements studied have a relationship with the assessment of the application of risk management in X Hospital. Various efforts have been made to protect doctors and nurses with the implementation of risk management that has been running quite well, as can be seen from the decrease in the number of infections during routine examinations. Obstacles are still found in the form of limited resources, lack of disciplined character, and the lack of fully honest communication and environment.

Keywords: risk management, COVID-19, doctors, nurses 


\section{Pendahuluan}

Pandemi virus novel corona 2019 (COVID-19) menyebar begitu cepat ke seluruh dunia menyebabkan krisis kesehatan masyarakat global. Berawal dari Wuhan, kini virus COVID19 sudah menyerang negara di seluruh dunia dengan kenaikan kasus yang masih mengkhawatirkan setiap harinya, tidak terkecuali Indonesia. Sebagai lini terdepan dalam menghadapi pandemi COVID-19, dokter dan perawat yang bertugas di fasilitas kesehatan, termasuk rumah sakit (RS), memiliki risiko terbesar untuk tertular virus COVID-19. Per 29 September 2020, tercatat 228 dokter dan perawat yang meninggal dunia akibat terinfeksi COVID-19, yang terdiri dari 127 dokter, 9 dokter gigi, dan 92 perawat (1).

Rumah sakit harus melakukan upaya-upaya perlindungan terhadap dokter dan perawatnya. Permenkes No. 27 Tahun 2017 menyatakan bahwa upaya mencegah dan meminimalkan terjadinya infeksi pada pasien, petugas, pengunjung, dan masyarakat sekitar fasilitas pelayanan kesehatan disebut dengan Pencegahan dan Pengendalian Infeksi (PPI). Pelaksanaan PPI adalah wajib di setiap rumah sakit sebagai salah satu jenis Standar Pelayanan Minimal Rumah Sakit (SPM) seperti yang tercantum di dalam Keputusan Menteri Kesehatan Republik Indonesia Nomor 129 Tahun 2008 tentang Standar Pelayanan Minimal Rumah Sakit (2). Standar pelaksanaan program PPI di RS tercantum di dalam Standar Nasional Akreditasi Rumah Sakit (SNARS). Selain standar PPI, juga terdapat standar lain yang berfokus pada perlindungan terhadap keselamatan staf RS, yaitu standar Peningkatan Mutu Dan Keselamatan Pasien (PMKP) dan standar Kompetensi dan Kewenangan Staf (KKS) 8.2 (3). Ketiga standar tersebut menekankan pada adanya program manajemen risiko yang berkelanjutan

Manajemen risiko dapat didefinisikan sebagai sebuah usaha yang terorganisir untuk mengidentifikasi, menilai potensi risiko serta mengurangi potensi risiko yang mungkin terjadi pada pasien, pengunjung, staff, dan aset organisasi (4). Manajemen risiko sebaiknya dilakukan secara proaktif dengan terus mengidentifikasi risiko yang mungkin terjadi dan cara pencegahannya (5). Berdasarkan ISO 31000, manajemen risiko merupaka sebuah proses yang terdiri dari menentukan konteks, identifikasi risiko, analisis risiko, evaluasi risiko, dan perlakuan risiko yang diikuti dengan adanya komunikasi dan konsultasi serta pemantauan dan tinjauan(6). Briner et al. (2010) menyatakan bahwa ada beberapa elemen kunci dari keberhasilan penerapan manajemen risiko, yaitu pendekatan sistematis (integrasi organisasi, kewenangan, alokasi sumber data, tujuan strategis dan operasional), implementasi manajemen risiko, kepemimpinan, pastisipasi staf, budaya keselamatan, pembelajaran dan pengembanganm pelatian, pelaporan insiden, dokumentasi serta komunikasi dan informasi.(7) Elemen-elemen kunci tersebut dikatakan dapat menentukan derajat kematangan manajemen risiko.(8)

RS X adalah sebuah rumah sakit swasta tipe B di Jakarta yang telah terakreditasi paripurna kedua kalinya di tahun 2019. RS X telah mulai memberikan pelayanan untuk pasien terinfeksi COVID-19 sejak Maret 2020. Berbagai penyesuaian dilakukan oleh $\mathrm{RS} X$ secara bertahap, seperti penyediaan ruang isolasi, unit gawat darurat (UGD) khusus COVID-19, sistem zonasi dan jalur khusus transportasi pasien, ruang operasi khusus pasien dengan COVID-19, dan sebagainya. Hingga saat ini, RS $X$ memiliki total 30 bed perawatan COVID-19, dengan alokasi 26 bed di ruang perawatan isolasi dan 4 bed di ICU. Berdasarkan wawancara singkat dengan salah satu jajaran manajemen RS X, hingga September 2020 sudah ada 1 dokter paruh waktu terkonfirmasi positif COVID-19 di RS X yang meninggal dunia serta ada beberapa dokter jaga dan perawat yang terkonfirmasi positif COVID-19. Namun, sulit untuk memastikan bahwa dokter dan perawat yang terkonfirmasi positif COVID-19 tertular saat menjalankan tugas di RS $\mathrm{X}$. Perubahan-perubahan yang dilakukan untuk menghadapi pandemi yang baru dan masih 
berjalan membuat proses manajemen risiko menjadi penting untuk dilakukan

Berdasarkan hal di atas, penulis memandang bahwa penelitian mengenai analisis penerapan manajemen risiko penularan infeksi COVID-19 pada dokter dan perawat di RS $X$ sebagai penyelenggara layanan perawatan COVID-19 adalah penting. Penelitian ini bertujuan untuk menganalisis penerapan manajemen risiko dalam pencegahan penularan infeksi COVID-19 pada dokter dan perawat di RS $X$ dengan mengetahui upaya-upaya yang telat dilakukan RS terkait perlindungan dokter dan perawat, menganalisis elemen-elemen penting dalam penerapan manajemen risiko, serta melihat hubungan antara elemen-elemen tersebut terhadap penilaian penerapan manajemen risko.

\section{Metode Penelitian}

Penelitian ini menggunakan metode penelitian kuantitatif dan kualitatif paralel konvergen, dimana penelitian kualitatif dan kuantitatif dilakukan bersamaan yang kemudian dilakukan pembahasan mengenai gabungan dari hasilnya untuk kemudian diambil kesimpulan. Penelitian dilakukan di RS $X$ di Jakarta dengan periode. Penelitian November 2020-Juni 2021. Metode penelitian kuantitatif digunakan untuk mengetahui partisipasi staf dalam pelaporan insiden sebagai salah satu dasar untuk proses manajemen risiko. Data kualitatif didapatkan melalui wawancara mendalam untuk melihat gambaran elemen-elemen kunci dari penerapan manajemen risiko dari sisi staff manajerial. Data kuantitatif didapatkan melalui penyebaran kuesioner daring kepada dokter dan perawat fungsional yang terdiri dari 17 pertanyaan terkait elemen-elemen kunci yang diteliti, yang kemudia dilakukan analisis hubungan antara elemen-elemen tersebut terhadap penilaian penerapan manajemen risiko di RS X.

Populasi pada penelitian ini adalah seluruh dokter dan perawat fungsional yang masih aktif dalam pelayanan pasien, serta jajaran manajemen terkait dalam usaha pengendalian dan pencegahan infeksi di RS. Teknik sampling untuk penelitian kualitatif dilakukan dengan teknik purposive sampling, yang kemudian didapatkan informan yaitu Direktur Pelayanan Medis, Kepala Bagian Mutu, Kepala Komite Medis, dan Kepala Komite Keperawatan. Untuk penelitian kuantitatif, dilakukan simple random sampling dengan total responden 84 orang.

Analisis data dilakukan secara univariat dan bivariat. Analisis bivariat dilakukan dengan mengginakan uji korelasi Spearman dengan hipotesis $0(\mathrm{HO})$ yaitu tidak ada hubungan antara variabel dari elemen-elemen penerapan manajemen risiko (partisipasi staf, pelaporan insiden, komunikasi dan informasi, pelatihan, pembelajaran dan pengembangan) terhadap penilaian baiknya penerapan manajemen risiko; serta hipotesis 1 (H1) yaitu ada hubungan antara variabel dari elemen-elemen penerapan manajemen risiko (partisipasi staf, pelaporan insiden, komunikasi dan informasi, pelatihan, pembelajaran dan pengembangan) terhadap penilaian baiknya penerapan manajemen risiko. Kemudian dilakukan perbandingan nilai $p$-value dengan 0.05 . Jika $p$ value yang dihasilkan lebih kecil dari 0.05 , maka $\mathrm{HO}$ ditolak dan $\mathrm{H} 1$ diterima. Jika $p$-value yang dihasilkan lebih besar dari 0.05 , maka HO diterima dan $\mathrm{H} 1$ ditolak.

\section{Hasil}

Uji validitas Karl Pearson dan uji reliabilitas Alpha Cronbach dilakukan terhadap instrumen kuesioner dalam penelitian ini. Pada uji validitas didapatkan hasil $r_{\text {hitung }}$ dari tiap point pertanyaan lebih besar dari $r_{\text {tabel }}(0.215)$ yang menunjukkan bahwa setiap variabel penelitian di dalam kuesioner adalah valid. Pada uji reliabilitas didapatkan nilai Alpha Cronbach dari setiap poin pertanyaan adalah $>0.06$ yang menunjukkan bahwa kuesioner reliabel. elemen-elemen penting dalam penerapan manajemen risiko klinis serta penerapan manajemen risiko itu sendiri.

Berikut ini adalah gambaran umum karakteristik subjek penelitian kuantitatif yang didapatkan dari pengisian kuesioner: 


\begin{tabular}{lcc}
\hline \multicolumn{1}{c}{ Karakteristik } & $\mathrm{n}$ & $\%$ \\
\hline Lokasi tugas & & \\
Zona merah & 66 & 78,6 \\
Bukan zona merah & 18 & 21,4 \\
Profesi & & \\
Dokter & 30 & 35,7 \\
Perawat & 54 & 64,3 \\
$\quad$ Perawat di zona merah & 36 & 66,7 \\
$\quad$ Perawat tidak di zona merah & 18 & 33,3 \\
\hline
\end{tabular}

Terdapat sejumlah 84 responden yang mengisi kuesioner, yang terdiri dari 30 dokter umum $(35,7 \%)$ dan 54 perawat (64,3\%). Dapat dilihat dari tabel 6.2 .1 bahwa, 78,6\% dari responden bertugas di zona merah, yang disebut sebagai area pelayanan COVID-19.

Tabel 2. Gambaran deskriptif jawaban responden

\begin{tabular}{|c|c|c|c|c|c|c|}
\hline \multirow{2}{*}{\multicolumn{2}{|c|}{ Komponen Manajemen Risiko }} & STS & TS & $\mathrm{N}$ & $S$ & SS \\
\hline & & $\%$ & $\%$ & $\%$ & $\%$ & $\%$ \\
\hline \multicolumn{7}{|c|}{ Partisipasi Staf } \\
\hline 1 & Mematuhi SPO keselamatan kerja & 2,4 & 1,2 & 11,9 & 45,2 & 39,3 \\
\hline 2 & $\begin{array}{l}\text { SPO keselamatan kerja cukup melindungi } \\
\text { pekerja }\end{array}$ & 2,4 & 0 & 17,9 & 57,1 & 22,6 \\
\hline 3 & Alat pelindung diri yang disediakan RS cukup & 1,2 & 2,4 & 16,7 & 60,7 & 19,0 \\
\hline 4 & Peraturan shift kerja cukup aman & 1,2 & 3,6 & 29,8 & 54,8 & 10,7 \\
\hline \multicolumn{7}{|c|}{ Pelaporan insidens } \\
\hline 1 & Mudah melaporkan insidens yang ditemukan & 1,2 & 1,2 & 21,4 & 64,3 & 11,9 \\
\hline 2 & $\begin{array}{l}\text { Tidak takut melaporkan insidens yang } \\
\text { ditemukan }\end{array}$ & 3,6 & 3,6 & 20,2 & 59,5 & 13,1 \\
\hline 3 & Mendapat informasi pelaporan insidens & 1,2 & 4,8 & 32,1 & 50,0 & 11,9 \\
\hline \multicolumn{7}{|c|}{ Komunikasi dan Informasi } \\
\hline 1 & Aktif mengidentifikasi risiko bagi & 1,2 & 4,8 & 21,4 & 63,1 & 9,5 \\
\hline 2 & Tersedia wadah diskusi oleh manajemen & 1,2 & 2,4 & 26,2 & 64,3 & 6,0 \\
\hline 3 & $\begin{array}{l}\text { Dorongan lingkungan kerja untuk jujur dan } \\
\text { komunikasi terbuka }\end{array}$ & 1,2 & 4,8 & 13,1 & 69,0 & 11,9 \\
\hline \multicolumn{7}{|c|}{ Pelatihan } \\
\hline 1 & Mendapat pelatihan cara identifikasi risiko & 2,4 & 13,1 & 32,1 & 47,6 & 4,8 \\
\hline 2 & Mendapat pelatihan keselamatan kerja & 2,4 & 11,9 & 23,8 & 56,0 & 6,0 \\
\hline 3 & Mendapat pelatihan pelaporan risiko & 2,4 & 13,1 & 20,2 & 57,1 & 7,1 \\
\hline 4 & Mendapat pelatihan pelaporan insidens & 2,4 & 14,3 & 20,2 & 56,0 & 7,1 \\
\hline 5 & Pelatihan manajemen risiko sudah memadai & 2,4 & 13,1 & 29,8 & 48,8 & 6,0 \\
\hline \multicolumn{7}{|c|}{ Pembelajaran dan Pengembangan } \\
\hline 1 & Pernah mengisi survey keselamatan kerja & 3,6 & 29,8 & 33,3 & 31,0 & 2,4 \\
\hline 2 & $\begin{array}{l}\text { Lingkungan kerja memperhatikan keselamatan } \\
\text { kerja }\end{array}$ & 1,2 & 6,0 & 35,7 & 48,8 & 8,3 \\
\hline \multicolumn{7}{|c|}{ Manajemen Risiko } \\
\hline 1 & $\begin{array}{l}\text { RS menerapkan manajemen terkait penularan } \\
\text { COVID-19 bagi tenaga kesehatan }\end{array}$ & 1,2 & 2,4 & 21,4 & 60,7 & 14,3 \\
\hline
\end{tabular}

STS: Sangat tidak setuju, TS: Tidak setuju, N: Netral, S: Setuju, SS: Sangat setuju 
Tabel 2 menunjukkan bahwa mayoritas responden setuju terhadap pertanyaanpertanyaan yang diajukan terkait implementasi elemen-elemen kunci manajemen risiko. $78 \%$ dari responden setuju bahwa RS telah menerapkan manajemen risiko yang baik dalam melindungi responden dari COVID-19.

Dari wawancara mendalam didapatkan bahwa RS $X$ telah melakukan berbagai upaya dalam mewujudkan lingkungan kerja yang aman bagi dokter dan perawat Pada elemen intergrasi organisasi, didapatkan bahwa RS telah memiliki sebuah tim COVID yang terdiri dari tim Pinere (dokter penanggung jawab dan dokter jaga) serta perwakilan dari seluruh bagian yang terkait pelayanan, seperti bagian medis, bagian penunjang dan bagian non-medis yang terdiri dari bagian rekam medis, rumah tangga, gizi, keamanan, hingga marketing. Pada elemen sumber daya, didapatkan bahwa belum ada alokasi sumber daya manusia (SDM) yang dikhususkan untuk tim manajemen risiko. Begitu pula dengan sumber daya finansial, dimana belum ada alokasi khusus untuk manajemen risiko maupun perekrutan staf terkait manajemen risiko yang disebabkan oleh adanya tantangan finansial yang sedang dihadapi akibat penurunan pemasukan RS dari pelayanan non-COVID selama pandemi. Fokus dari alokasi sumber daya saat ini, baik manusia maupun finansial, adalah pada pelayanan.

Pada elemen tujuan strategis dan operasional didapatkan bahwa tujuan strategis penerapan manajemen risiko terkait penularan COVID pada dokter dan perawat di RS X menurut para informan adalah tidak adanya penularan COVID pada dokter dan perawat saat memberikan pelayanan, baik dari pasien maupun dari sesama tenaga medis di RS. Sedangkan tujuan operasionalnya adalah tiap unit kerja dapat menjalankan perannya dengan baik guna mencapai tujuan stragegisnya. Namun, kedua tujuan tersebut belum didokumentasikan secara resmi sebagai kebijakan.

Pada elemen penerapan manajemen risiko terkait penularan COVID-19 pada dokter dan perawat di RS X, informan mengatakan bahwa proses manajemen risiko sudah dijalankan cukup baik, mulai dari identifikasi hingga perlakuan risiko. Namun, mayoritas kebijakan dan SOP manajemen risiko khusus COVID-19 belum diresmikan sehingga hanya berupa notulensi rapat. RS X telah melakukan berbagai upaya mitigatif sebagai perlakuan dari risiko penularan COVID-19, antara lain adanya pemisahan area pelayanan khusus COVID-19 dengan fasilitas berupa IGD khusus COVID-19, ruang isolasi bertekanan negatif, ICU COVID19 , serta ruang bedah khusus pasien COVID-19. Dilakukan juga zonasi dan pemisahan pintu masuk, baik bagi pasien terkonfirmasi/suspek COVID-19 dengan pasien non-COVID maupun antara staf dan pengunjung. RS $X$ juga menerapkan sistem zonasi. RS $X$ juga melakukan penyesuaian shift kerja yang awalnya 8 jam/shift menjadi 6 jam/shift. RS X juga selalu memastikan bahwa alat pelindung diri (APD) selalu tersedia sesuai dengan level kebutuhan. Untuk pasien rawat inap, RS X juga meneraplan metode double screenin dimana calon pasien rawat inap akan melakukan swab antigen, swab PCR, serta melewati penliaian foto toraks dada dan hasil lab darah oleh tim Pinere.

Pada elemen kepemimpinan, didapatkan bahwa pimpinan RS $X$ sudah cukup aktif dalam melakukan upaya-upaya manajemen risiko terkait COVID. Diskusi mengenai risiko yang teridentifikasi juga dianggap sangat baik. Morning Report yang digelar setiap hari secara langsung menjadi wadah untuk laporan mengenai hal-hal yang sekiranya perlu dibahas. Morning report ini dihadiri oleh wakil direktur, dokter jaga, dokter penanggung jawab, dan pihak terkait lainnya. Selain pembahasan lewat rapat tatap muka, ada juga pembahasan secara virtual, baik lewat diskusi di grup whatsapp maupun rapat virtual.

Pada elemen partisipasi staf didapatkan bahwa staf dianggap sudah cukup patuh dengan kebijakan yang dibuat oleh rumah sakit terkait manajemen risiko, termasuk pencegahan penularan COVID. Staf juga cukup aktif dalam melaporkan risiko atau insiden yang mereka temukan saat bekerja. Namun, masih ada beberapa staf yang takut untuk jujur dan melaporkan temuannya. Pelaporan biasanya dilakukan langsung ke penanggung jawab 
ataupun via grup whatsapp. Umpan balik yang diberikan manajemen terkait pelaporan pun dinilai sudah cukup baik. Selain itu, pada elemen ini masih ditemukan sebuah celah penularan COVID-19 terhadap staf, dimana kebiasaan staf untuk makan bersama menjadi sebuah kegiatan yang berisiko. Dari penelitian juga didapatkan bahwa RS $X$ cukup memperhatikan gizi staf dengan adanya pemberisan asupan snack bergizi dan vitamin. Namun, untuk makanan utama, RS $X$ hanya menyediakan makanan untuk staf di area COVID-19, sehingga staf di luar area tersebut masih sering membeli makanan sendiri di luar RS. Ini juga merupakan sebuah celah penularan.

Pada elemen pelatihan didapatkan bahwa belum adanya pelatihan terkhusus manajemen risiko terkait COVID-19. Sebelum COVID, ada pelatihan terkait manajemen risiko dan identifikasi serta pelaporan insiden. Namun, ketika pandemi COVID, pelatihan ditiadakan. Namun, secara internal, ada pemberian edukasi yang terbilang masuk ke dalam langkah manajemen risiko terkait COVID juga, seperti pelatihan cara lepas-pasang APD dari diklat untuk karyawan baru.
Pada elemen komunikasi dan informasi didapatkan bahwa untuk komunikasi pelaporan kejadian tidak terduga saat ini dianggap cukup terkendala karena banyaknya staf yang mengundurkan diri. Laporan mengenai KTD tetap dibuat dan dibahas via rapat daring untuk melakukan risk analysis. Namun, dilakukan hanya untuk kejadian dengan risiko tinggi. Sedangkan untuk kejadian-kejadian kecil tidak dilakukan. Menurut informan, lingkungan jujur dan komunikasi terbuka tentang temuan-temuan dari staf belum sepenuhnya tercipta. Masih ada beberapa staf yang tidak jujur dan takut untuk melaporkan temuannya.

Pada elemen pembelajaran dan pengembangan didapatkan bahwa terdapat wadah diskusi terkait risiko-risiko yang ditemukan dilakukan lewat grup whatsapp, dimana risiko yang ada akan langsung dibahas dan mulai perencanaan untuk tidak lanjut. Terkait survey, survey keselamatan kerja untuk dokter dan perawat belum pernah dilakukan secara menyeluruh. Namun, ketua komite keperawatan pernah membuat kuesioner mandiri yang disebarkan ke perawat

\section{Analisis Korelasi}

Tabel 5. Analisis korelasi hubungan tiap komponen manajemen risiko dengan Uji Korelasi Spearman

\begin{tabular}{lcccccc}
\hline $\begin{array}{c}\text { Komponen Manajemen } \\
\text { Risiko }\end{array}$ & $\begin{array}{c}\text { Partisipasi } \\
\text { Staf }\end{array}$ & $\begin{array}{c}\text { Pelaporan } \\
\text { Insiden }\end{array}$ & $\begin{array}{c}\text { Komunikasi } \\
\text { dan } \\
\text { Informasi }\end{array}$ & Pelatihan & $\begin{array}{c}\text { Pembelajaran } \\
\text { dan } \\
\text { Pengembangan }\end{array}$ & $\begin{array}{c}\text { Manajemen } \\
\text { Risiko }\end{array}$ \\
\hline Partisipasi Staf & & 0,504 & 0,426 & 0,308 & 0,318 & 0,601 \\
$\begin{array}{l}\text { Pelaporan Insiden } \\
\text { Komunikasi dan Informasi }\end{array}$ & 0,504 & & 0,543 & 0,404 & 0,332 & 0,425 \\
$\begin{array}{l}\text { Pelatihan } \\
\text { Pembelajaran dan }\end{array}$ & 0,426 & 0,543 & & 0,472 & 0,472 & 0,607 \\
$\begin{array}{l}\text { Pengembangan } \\
\text { Manajemen Risiko }\end{array}$ & 0,318 & 0,404 & 0,472 & & 0,513 & 0,525 \\
\hline
\end{tabular}

*seluruh korelasi memiliki nilai $p<0.05$

Dari tabel 3 dapat dilihat bahwa keseluruhan dimensi memiliki korelasi moderat hingga kuat terhadap manajemen risiko di mana hasil uji korelasi Spearman menunjukkan hasil dari $0,425-0,607$. Seluruh dimensi dari variabel $X$ menunjukkan nilai $p<0,05$ yang menunjukkan bahwa $\mathrm{HO}$ ditolak dan $\mathrm{H} 1$ diterima.

\section{Pembahasan}

Dari hasil penelitian, didapatkan bahwa RS $X$ sudah cukup aktif dalam melakukan upayaupaya perlindungan terhadap dokter dan perawat dari penularan COVID-19 di tempat kerja. Ini sesuai dengan pernyataan Adibi et al., 
dimana organisasi pelayanan kesehatan wajib menyediakan lingkungan yang aman baik untuk pasien maupun staf (9). Pemisahan area pelayanan COVID-19 dianggap langkah yang baik dalam menghadapai dimana upaya pemisahan ruang fisik ketika terjadi outbreak, pandemi atau epidemi sebagai upaya pengendalian faktor lingkungan telah dilakukan semenjak dahulu (10). Sesuai dengan pernyataan Tingbo Liang (11) bahwa langkah pencegahan penularan dan manajemen kontrol di RS dengan pelayanan COVID-19 adalah dengan mengupayakan adanya area isolasi, RS $\mathrm{X}$ telah menyediakan area khusus pelayanan COVID-19 yang juga dilengkapi dengan akses masuk terpisah dan dilakukan penapisan gejala. RS X juga sudah menyediakan APD yang adekuat yang juga didukung oleh adanya konvergensi antara hasil penelitian kualitatif dan kuantitatif. dimana didapatkan 77\% dokter dan $85,1 \%$ perawat setuju bahwa RS telah menyediakan APD yang memadai dan cukup melindungi dari risiko tertular virus COVID-19.

Pemendekkan shift kerja yang dilakukan RS $\mathrm{X}$ tidak sejalan dengan penelitian terdahulu dari Chua et al. (12) yang justru menunjukkan bahwa pemanjangan durasi shift, dari 8 jam/shift menjadi 12 jam/shift, menuai respon positif dari tenaga kesehatan dimana dengan shift yang lebih panjang, tenaga kesehatan bisa mendapatkan hari istirahat yang lebih banyak. Modifikasi ini dikatakan memiliki efek positif pada kesehatan fisik dan mental. Minimnya pertukaran shift juga meminimalisir operan, interaksi dengan tenaga kesehatan lain dan meminimalisir pemakaian APD. Namun, memanjangnya durasi kerja juga perlu diiringi dengan hari libur yang lebih panjang, sehingga diharapkan para staf mendapatkan wakut istirahat yang cukup panjang dan efektif. Menurut Poonian et al, pilihan terbaik adalah pengaturan shift dengan durasi lebih panjang yang kemudian diikut 3 hari libur, serta adanya libur panjang yaitu selama 1 minggu setiap 4-5 minggu. Selain itu, pemendekan durasi shift juga dapat berdampak pada semakin banyaknya kebutuhan APD yang elain dapat meningkatkan pengeluaran RS terkait APD, keadaan ini juga dapat menambah limbah APD. Diharapkan juga pemanjangan shift dapat mengurangi beban alokasi SDM, sehingga RS dapat mulai mengalokasikan SDM untuk proses manajemen risiko.

Secara keseluruhan, 9 elemen implementasi manajemen risiko yang diteliti menunjukkan hasil yang cukup baik. Mulai dari integrasi organisasi, alokasi sumber daya, tujuan strategis dan operasional, penerapan manajemen risiko, kepemimpinan, partisipasi staf, pelatihan, komunikasi dan informasi, serta pembelajaran dan pengembangan. Ini didukung oleh adanya konvergensi antara hasil penelitian kualitatif dan juga kuantitatif terhadap elemen-elemen tersebut. Baiknya implementasi elemen-elemen tersebut terlihat dari adanya penurunan angka dokter dan perawat yang terinfeksi pada swab rutin. Elemen-elemen tersebut juga memiliki korelasi moderat hingga kuat terhadap penilaian baiknya penerapan manajemen risiko di RS $X$ dengan korelasi moderat pada elemen pelaporan insiden, pelatihan serta pembelajaran dan pengembangan. Sedangkan korelasi kuat didapatkan pada elemen partisipasi staf serta komunikasi dan informasi.

Namun, masih ada beberapa hal yang perlu menjadi perhatian, salah satunya adalah belum adanya kebijakan resmi terkait manajemen risiko COVID-19. Dimana menurut Van Meter Van Horn (1975) di dalam Sulaeman (1998), diperlukan adanya standar dan sasaran yang jelas untuk dijadikan landasan penilaian kinerja kebijakan.(13) Terkait sumber daya finansial, RS X perlu melakukan beberapa upaya adaptif untuk meingkatkan pemasukan dari pelayanan non-COVID, salah satu langkah yang dapat dilakukan adalah dengan penyediaan layanan konsultasi daring. Karena berdasarkan penelitian terdahulu, kurangnya sumber keuangan merupakan salah satu faktor penghambat terciptanya manajemen risiko yang baik (9).

\section{Kesimpulan}

Dapat disimpulkan bahwa RS $\mathrm{X}$ telah melakukan berbagai upaya perlindungan terhadap dokter dan perawatnya, antara lain pemisahan area pelayanan COVID-19, 
pemisahan pintu masuk baik antara staf dan pasien juga antar pasien terkonfirmasi/suspek dengan non-COVID, double screening untuk pasien rawat inap, sistem zonasi, penyesuain shift kerja, penyediaan APD yang adekuat, serta adanya screening bulanan. RS $X$ telah menerapkan manajemen risiko yang cukup baik dan terus berproses menjadi lebih baik, yang tercermin dari adanya penurunan yang berarti dari angka positif COVID-19 dokter dan perawat pada pemeriksaan rutin bulanan. Terdapat hubungan yang moderat hingga kuat antara elemen partisipasi staf, pelaporan insiden, komunikasi dan informasi, pelatihan, serta pembelajaran dan pengembangan terhadap penilaian penerapan manajemen risiko penularan COVID-19 pada dokter dan perawat di RS X.

\section{Saran}

Perlu adanya peresmian peraturan-peraturan terkait manajemen risiko COVID-19 untuk menjadi sebuah kebijakan dan SOP sebagai standar yang kemudian dapat digunakan untuk acuan evaluasi. Disarankan untuk dilakukan peninjauan ulang terhadap perubahan durasi shift yang sedang berlaku mengingat saat ini RS mengalami kendala berupa kurangnya SDM. Dalam upaya untuk meningkatkan pemasukan RS, perlu dipikirkan untuk diselenggarakannya konsultasi secara daring serta penyebaran informasi mengenai layanan non-COVID yang aman lewat media sosial. Adanya koordinasi dari RS terkait makanan staf. Dapat dipertimbangkn untuk penyediaan makanan untuk staf dari rumah sakit agar gizi dan keamanan staf lebih terjamin. Atau dapat kembali ke regulasi hanya diperbolehkan membeli makan secara online demi meminimalisir risiko penularan di luar RS. Dengan masiih berlangsungnya pandemi dan masih bermutasinya virus COVID-19, perlu dilakukan penelitian lanjutan untuk memastikan bahwa manajemen risiko yang dilakukan masih efektif dalam melindungi dokter dan perawat dari varian-varian virus COVID-19 yang baru.

\section{Daftar Pustaka}

1. Azanella LA. Data IDI hingga 26

September 2020: Data IDI hingga 26

September 2020: 123 Dokter

Meninggal Dunia karena Covid-19

[Internet]. 2020 [dikutip 6 Oktober

2020]. Tersedia pada:

https://www.kompas.com/tren/read/2

020/09/28/100643465/data-idi-hingga-

26-september-2020-123-dokter-

meninggal-dunia-karena-

covid?page=all

2. Menteri Kesehatan RI. Peraturan

Menteri Kesehatan Nomor 129 Tahun

2008 TENTANG STANDAR PELAYANAN

MINIMAL RUMAH SAKIT MENTERI

KESEHATAN REPUBLIK INDONESIA.

Nomor Tambah Lembaran Negara

Nomor 4355 Nomor Tambah Lembaran

Negara Nomor 4400. 2008;1(5):1-55.

3. SNARS. Standar Akreditasi Rumah

Sakit. Standar Akreditasi Rumah Sakit.

2018;421.

4. Kavaler F, Spiegel AD. Risk

Management in Healt Care Institutions:

A Strategic Approach. 2003.

5. Alam AY. Steps in the Process of Risk

Management in Healthcare. J

Epidemiol Prev Med. 2016;02(02).

6. Susilo L, Kaho VR. Manajemen Risiko Berbasis ISO 31000 Untuk Industri Nonperbankan. 2011.

7. Briner $\mathrm{M}$, Kessler $\mathrm{O}$, Pfeiffer $\mathrm{Y}$, Wehner $T$, Manser T. Assessing hospitals' clinical risk management: Development of a monitoring instrument. BMC Health Serv Res. 2010;10.

8. Briner M, Manser T, Kessler O. Clinical risk management in hospitals: Strategy, central coordination and dialogue as key enablers. J Eval Clin Pract. 2013;19(2):363-9.

9. Adibi $H$, Khalesi $N$, Ravaghi $H$, Jafari $M$, Jeddian AR. Development of an effective risk management system in a teaching hospital. J Diabetes Metab Disord. 2012;11(1):1-7.

10. Yassi A, Moore D, Fitzgerald JM, Bigelow $\mathrm{P}$, Hon CY, Bryce E. Research gaps in protecting healthcare workers from SARS and other respiratory pathogens: An interdisciplinary, multi- 
stakeholder, evidence-based approach. J Occup Environ Med. 2005;47(1):4150.

11. Liang T. Handbook of COVID-19 Prevention and Treatment. Handb Covid-19, Prev Treat [Internet]. 2020;68. Tersedia pada: https://covid19.conacyt.mx/jspui/handle/1000/25\% OAhttps://covid-19.alibabacloud.com/
12. Chua WLT, Quah LJ, Shen Y, Zakaria Di, Wan PW, Tan K, et al. Emergency department $€$ outbreak rostering' to meet challenges of COVID-19. Emerg Med J. 2020;37(7):407-10.

13. Sulaeman A. Public Policy- Kebijakan Pemerintah. BKU Ilmu Pemerintah Progr Magister Ilmu-ilmu Sos. 1998; 